Open Access

\title{
Asthma and COPD - The C/EBP Connection
}

\author{
Nicola Miglino, Michael Roth, Michael Tamm and Peter Borger ${ }^{*}$
}

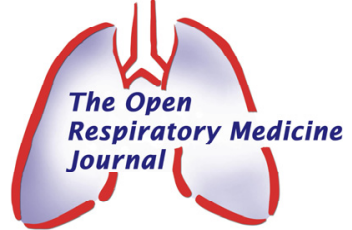

Pulmonary Cell Research, Departments of Biomedicine and Pneumology, University Hospital Basel, Switzerland

\begin{abstract}
Asthma and chronic obstructive pulmonary disease (COPD) are the two most prominent chronic inflammatory lung diseases with increasing prevalence. Both diseases are associated with mild or severe remodeling of the airways. In this review, we postulate that the pathologies of asthma and COPD may result from inadequate responses and/or a deregulated balance of a group of cell differentiation regulating factors, the CCAAT/Enhancer Binding Proteins (C/EBPs). In addition, we will argue that the exposure to environmental factors, such as house dust mite and cigarette smoke, changes the response of C/EBPs and are different in diseased cells. These novel insights may lead to a better understanding of the etiology of the diseases and may provide new aspects for therapies.
\end{abstract}

Keywords: Asthma, COPD, airway inflammation, airway wall remodelling, CCAAT-enhancer binding proteins.

\section{ASTHMA}

General background: The term asthma origins form the greek word 'asthmaino' ( $\alpha \sigma \tau \eta \mu \alpha v \omega)$, translated as 'gasping' and which was first used by Hippocrates (460-377 BC) in the Corpus Hippocraticum [1]. The Global Initiative for Asthma (GINA) defined asthma as a "chronic inflammatory disorder of the airways in which many cells and cellular elements play a role. The chronic inflammation is associated with airway hyper-responsiveness that leads to recurrent episodes of wheezing, breathlessness, chest tightness and coughing, particularly at night or in the early morning. These episodes are usually associated with widespread, but variable airflow obstruction within the lung that is often reversible either spontaneously or by treatment" [2]. This unifying definition of asthma highlights the clinical hallmarks of the disease: (i) the inflammatory process, (ii) the airway hyperresponsiveness, (iii) the obstruction of the airflow, and (iv) increased airway remodeling. Asthma is a very heterogeneous disease, as it includes immunopathology, clinical different phenotypes, non-uniform response to therapies and distinct natural histories [3]. Asthma can be considered as a syndrome with different risk factors, different prognosis, and different response to treatment [4, 5]. This indicates the need to rethink the definition of asthma as an inflammatory disease of the lung.

Although innate factors may have a genetic background, data analyses for genes associated with (1) increased production of IgE (atopy), (2) airway hyperrresponsiveness, or (3) the release of inflammatory mediators are rather inconsistent and provided no specific asthma-associated genes. However, a number of chromosomal regions were associated with asthma susceptibility and with the coinheritance of the tendency to produce elevated IgE serum levels together with airway hyper-responsiveness [6-9]. In a

*Address correspondence to this author at the Pulmonary Cell Research, University of Basel, Department of Biomedicine, Hebelstrasse 20, CH 4031 Basel, Switzerland; Tel: +61 41265 3254; Fax: +61 41265 2350;

E-mail: pieter.borger@unibas.ch genome-wide study, 79 genes were differentially expressed in cells of asthma patients relative to controls [10]. The expression pattern of these genes, however, was not straightforward but indicated complex interactions with several environmental risk factors. Known risk factors are obesity and male sex for childhood asthma [11]. Environmental risk factors that foster the development of asthma are indoor and outdoor allergens, such as house dust mite (HDM), cockroach allergens, cat and dog dander or Aspergillus mold. Especially, the exposure to allergens during childhood up to 3 years of age seems to be crucial for developing asthma-like symptoms [12-21]. Other risk factors are airway infections during childhood [22-25], occupational sensitisers [26-29], exposure to tobacco smoke [30-35], and the diet [36, 37]. There is considerable overlap of the mechanisms by which these risk factors may lead to the development of asthma. It is important to note that triggers for an asthmatic attack are not the same as factors that initiates asthma pathology. Many asthmatic subjects are atopic ( $60 \%$ of asthmatic adults, $80 \%$ of asthmatic children), but it is also true that not all atopic subjects develop asthma. Furthermore, $30 \%-50 \%$ of asthmatic subjects are not atopic, meaning that no circulating $\operatorname{IgE}$ against one or more common allergens are present. Therefore, IgE-mediated mast cell degranulation is neither necessary, nor sufficient to develop asthma [38-40].

\section{Pathogenesis of Asthma}

Airway inflammation: Airway inflammation is a multicellular process involving Th2 lymphocytes, eosinophils, activated mast cells, neutrohphils, macrophages and basophils. In atopic asthma, the airway responds to airborne inhaled allergens by a Th2 response with the release of a typical array of cytokines (Th2 paradigm) [3]. In the small and large airways of chronic asthma patients, the number of mast cells and airway smooth muscle (ASM) cells are increased. Activation of mast cells occurs after binding of $\operatorname{IgE}$ to the highaffinity $\operatorname{IgE}$ receptor (FCeRI) leading to the release of TNF- $\alpha$, IL-4 and IL-5. Mast cell-derived bronchioconstrictive mediators, such as leukotriene (LT) $\mathrm{D}_{4}$, 
prostaglandin $(\mathrm{PG}) \mathrm{D}_{2}$ and histamine, are potent ASM cell contractile agents $[41,42]$. Vice versa, ASM cells produce chemokines, cytokines, and growth factors (e.g. IL-8, SCF, CXCL8, CXCL10) that further recruite mast cells into the lung $[43,44]$. In addition, mast cell tryptase, a protease that activates protease activated-receptor type 2 (PAR2) on ASM cells induces muscle contraction [45].

Airway hyper-responsiveness: Airway hyperresponsivness is a characteristic functional abnormality of asthmatic lungs resulting in airway narrowing when stimulated [2]. In consequence, asthma patients suffer from airflow limitation. Airway hyperresponsivenss is linked to both airway inflammation and and airway remodeling and is partially reversible by bronchodilators One of the mechanism leading to AHR may be an excessive contraction of the increased mass of ASM cells and by the thickening of the airway wall due to extracellular matrix.

Airway remodelling: Airway remodeling in asthma includes thickening of the reticular basement membrane (RBM), epithelium fragility, hypertrophy of mucus secreting glands, hypertrophy and hyperplasia of ASM cells and increased deposition of extracellular matrix.

Damage and shedding of the airway epithelium is another important histological characteristic of asthma. Asthmatics patients often present clusters of epithelial cells (Creola bodies) in sputum and have increased numbers of epithelial cells in bronchoalveolar lavage fluid, which may result from the loss of airway epithelium observed in biopsy specimens $[46,47]$. Upregulation of epidermal growth factor receptors (EGFRs), impaired proliferation reduced expression of proliferative markers and upregulation of the cyclin inhibitor, nuclear $\mathrm{p} 21^{\text {Wafl/Cip } 1}$ indicated that the epithelium is chronically injured and the repair mechanism is impaired in asthma [48, 49]. Furthermore, the epithelium of asthmatic patients is more fragile and the tight junctions are weakened $[3,50]$, in consequence, the airway epithelium enters into a chronic "wound scenario" [51].

Epithelial-derived growth factors force mesenchymal cells to produce collagen, reticular and elastic fibers, as well as proteoglycans and glycoproteins of the extracellular matrix (ECM), all of which contribute to the thickness of the airway wall in asthmatic [52]. The increased volume of the inner airway wall has functional consequences in terms of lumen reduction. Fibroblasts and myofibroblasts further contribute to tissue remodeling by deposing ECM components such as elastin, fibronectin, and laminin [53]. Mast-cell derived serine protease is a potent stimulant of fibroblast and ASM cell proliferation and stimulates the synthesis of type I collagen by human fibroblasts [54]. The distinct histologies of asthma are shown in Fig. (1).

The airway smooth muscle cell: One of the most striking aspects of the pathology of airway remodeling in asthma is the increased number and size of ASM cells [55], which had been reported by Huber and Koesser in 1922. At that time, the ASM cells were considered the main cause of the airway hyper-responsiveness, and held responsible for the exaggerated airway constriction as observed in asthma [56]. Later, this concept was replaced by the hypothesis that asthma results from a deregulated immune response, which however can only explain allergic asthma. Interestingly, an increasing number of recent studies points back to the pathologic ASM cell as a major cause of asthma. What properties of the ASM cell would support this idea? As ASM cells are the effector cells controlling the airway caliber, it is reasonable to consider that dysfunction of ASM cells contributes to the pathophysiology of asthma. Today, asthma is defined as chronic inflammatory disease of the lung with an increased Th2-like response and with high levels of IL-4, IL-5, and IL-13 [2]. This view ignores that the increased mass of ASM cells already exists in very young children and does not correlate with the severity and duration of the disease [57-62]. Furthermore, airway inflammation is not
Non-Asthma

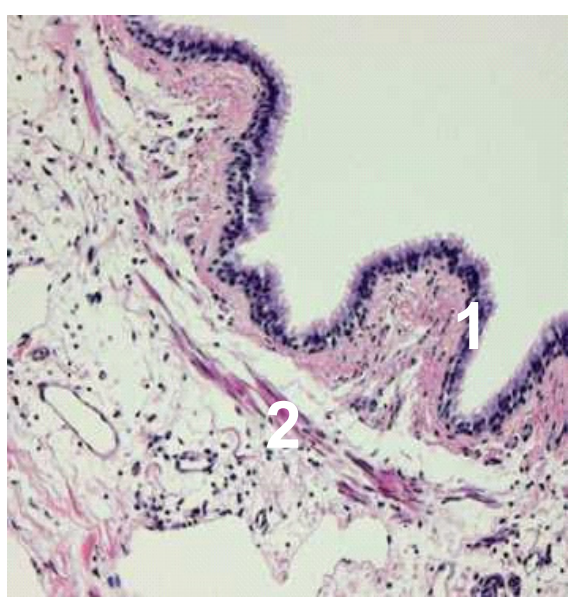

Mild-moderate Asthma

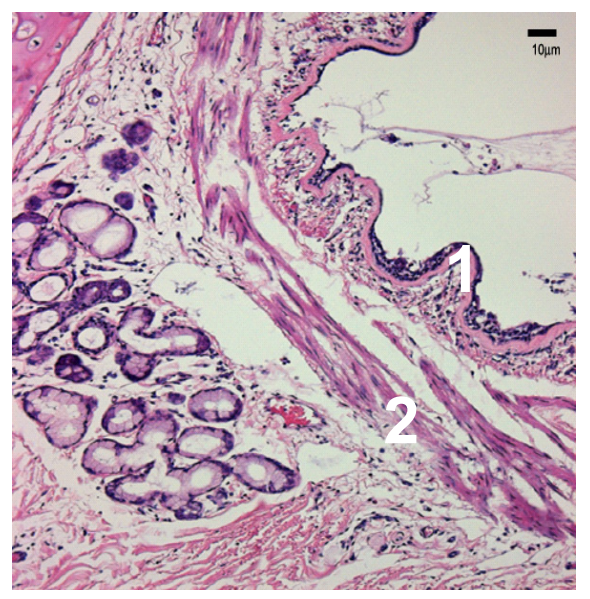

Severe Asthma

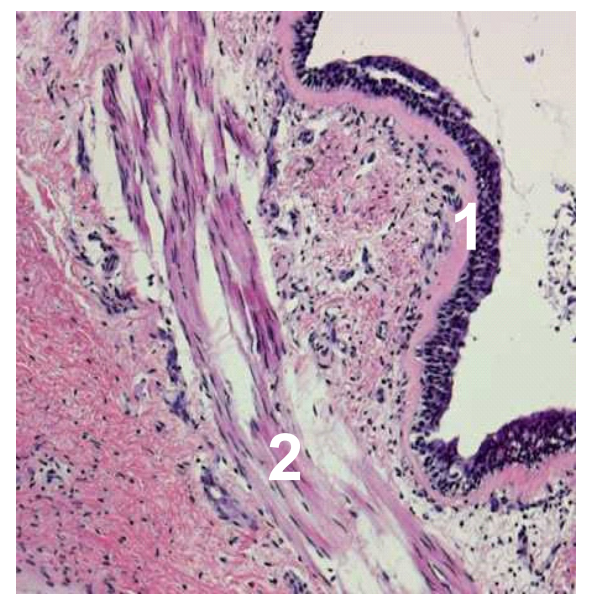

Fig. (1). Immunohistochemistry of a representative section of the airway of a non-asthma control, a patient with mild-to-moderate asthma, and a patient with asthma who died of status asthmaticus (as indicated). The asthmatic airway demonstrates typical thickening of the basement membrane (1), and the characteristic increased mass of smooth muscle cells (2) [Reprinted with permission of the American Thoracic Society. Copyright (c) American Thoracic Society. Borger P, Tamm M, Black JL, Roth M. Asthma: is it due to an abnormal airway smooth muscle cell? Am J Respir Crit Care Med. 2006 Aug 15; 174 (4): 367-72; Official Journal of the American Thoracic Society, Diane Gern, Publisher]. 
present in all patients with childhood asthma, whereas remodelling is $[59,63]$.

As reviewed by Borger et al. [64], asthma is a heterogeneous disease involving not only immune-mediated mechanisms. Studies using cyclosporine to block T-cell activation and thereby the release of IL-2, IL-4 and IL-5 showed only an effect on the late asthmatic response, suggesting that the early asthmatic response is not T-cell mediated $[65,66]$. The use of anti-IL-5 monoclonal antibodies reduced eosinophils by $80 \%$ in the airways and in the blood of asthmatic subjects but did not reduce in any clinical measures of asthma [67]. More recent studies, however, report beneficial effects of IL-5 antibody in eosinophilic asthma [68]. Interestingly the reduction of ASM cells mass by thermoplasty in the airway wall significantly improved asthma symptoms over a period of 3 years to date [69]. In the light of these findings, ASM cells may not be only effector cells that cause airway constriction as a consequence of the inflammatory process, but they may be initiator- or co-initiator of the disease. In line with this hypothesis, ASM cells produce IL-1, IL-2, IL-5, IL-6, IL-11 and IL-12, and are able to release TARC, a cytokine that induces Th2 migration and recruitment [70-74]. Therefore, ASM cell activity may initiate and orchestrate an inflammatory response and induce the recruitment of inflammatory cells into the lung. This capacity may be further enhanced through crosstalk with the airway epithelium.

Our group was the first to demonstrate that isolated ASM cells of asthmatic patients have the potential to proliferate faster than cells from control subjects under defined conditions [75]. This could explain the augmentation of ASM cell mass in the asthmatic airway. Importantly, this ASM cell pathology is maintained through weeks in culture and many passages long after any inflammatory mediator present in the tissue has been washed out. Furthermore, our group found that ASM cells from asthma patients are primed for IL-6 release [76, 77]. We can therefore speak of a constitutive activated phenotype of ASM cells in asthma patients.

\section{COPD}

General background: COPD is a chronic inflammatory lung disease that will be the third most frequent cause of death throughout the world. The Global Initiative for Chronic Obstructive Lung Disease defines COPD as " $a$ pulmonary disease characterised by airflow limitation that is not fully reversible. The airflow limitation is usually progressive and associated with an abnormal inflammatory response of the lung to noxious particles or gases" [78]. COPD affects $>10 \%$ of the world population over the age of 40 years [79] and every year almost 3 million people die of this disease [80, 81]. Despite of its global prevalence, there is still a fundamental lack of knowledge about the cellular, molecular and genetic causes of COPD and an efficient therapy is non-existing [82].

COPD involves host-dependent (genetic) and environmental factors, but undoubtedly the major cause, is cigarette smoking; it accounts for approximately $90 \%$ of all cases and there is a correlation between the tobacco consumption and severity of COPD. Furthermore, indoor air pollution from biomass fuel smoke is a major cuse of COPD in the developing world [83]. However, only $10-20 \%$ of people exposed to smoke develop COPD, which indicates that a genetic susceptibility has to be combined with environmental factors to induce COPD [84-86]. Mutations in the alpha-1 antitrypsin gene, which speciies a serine protease, lead to the development of emphysema, and decline in lung function due to digestion of the lung forming extracellular matrix and cell-cell interactions [87]. Mutations in genes of the detoxification proteins GSTM1 and GSTT1, also confer a risk for declining FEV1, especially in males, and this risk is further increased by smoking [88]. In addition, gene polymorphisms of the $A D A M 33$ [89], $D E C O R I N$ and TGFB1 genes confer the susceptibility to develop COPD [90]. Environmental COPD risk factors are occupational dust and chemical exposure [91-94], infections [95-98], the socioeconomic status [99]. Others regard COPD as an auto-immune disease with an aberrant response to antigens (e.g. elastin) released after smoking-induced tissue injuries [100].

\section{Pathogenesis of COPD}

Airway inflammation: The immune cells in the COPD lung are disease-specific with predominantly neutrophils, alveolar macrophages, and CD8 positive T-cells. Compared to "healthy" smokers, COPD patients with emphysema show a 25 -fold increase in the number of macrophages in the lung tissue and in the alveolar [95] and macrophage numbers in the airways correlated with the severity of COPD [101]. In COPD the inflammation occurs mainly in the peripheral airways (bronchioles), the lung parenchyma, and the pulmonary vessels. Distinct from asthma, the bronchioles of COPD lung are obstructed and present with fibrosis [102107].

Airway remodelling: In COPD, airway remodelling leading to airflow limitation is mainly observed in the small airways and lung parenchyma. In pulmonary emphysema, one of causes leading to defective alveolar regeneration is due to the malfunction of fibroblasts $[108,109]$. The major characteristic of airflow limitation in COPD is the fact that it is only partly reversible and progressive. In COPD, the thickness of the airway wall of small airway increases and thus limits the airflow. This is due to a high collagen deposition and mucosa thickening [110-114]. The increased ECM accumulation is thought to be a consequence of the chronic inflammatory process. Increased levels of TGF- $\beta$ are typical for COPD lungs and may cause the release of connective tissue growth factor (CTGF) which, in turn, stimulates collagen deposition in the airway wall [115-118]. Furthermore, inflammation destructs the alveolar wall leading to airway wall deformation and narrowing of the airway lumen which may ultimately lead to loss of lung tissue and emphysema [119].

Protease-antiprotease imbalance: The major hypothesis to explain COPD-associated emphysema is an imbalance of proteases and their inhibitors. This idea might result from the fact that congenital emphysema is caused by the deficiency of alpha- 1 antitrypsin, a protein that prevents the lung tissue from being digested by proteases. The lack of this protein accounts for $2 \%$ of COPD patients, with a substantial higher risk in smokers [87]. Unopposed, the 
activity of proteases induce lung damage similar to tissue structural changes seen in COPD-associated emphysema. In addition, matrix metalloproteinases (MMPs), may be involved in COPD since they induce morphological changes in the lung and increased concentrations of MMP-1, -2, -9, 12 were found in bronchoalveolar lavage samples of COPD patients [120, 121]. Since MMP-12 degrades elastin it is considered the leading proteinase responsible for pulmonary emphysema [122].

Cigarette smoke: Cigarette smoke is a complex mixture that consists of over 4,000 chemical components, including $10^{15}$ highly reactive molecules in the gas phase alone [123125]. In vitro, the biological effect of tobacco smoke can be studies using single compounds (e.g. nicotine), or cigarette smoke extracts (CSE), or smoke conditioned medium (SCM) [126] (Fig. 2). Cigarette smoke inhibits alveolar repair and hence contributes to tissue loss observed in emphysema [127]. CSE-stimulated lung fibroblasts release neutrophil and monocyte-attracting factors, including IL-8, granulocytemacrophage colony-stimulating factor (GM-CSF), and monocyte chemotactic protein-1 (MCP-1) [128]. Chronic cigarette smoke exposure increased the number of neutrophils, lymphocytes, and macrophages in the lung [129, 130]. Significant retention of activated neutrophils in the lung was observed after smoking [131]. In a mouse model, cigarette smoke increased desmosine in the lung, which indicates elastin fiber breakdown [132]. Compared to nonsmokers, exhaled breath condensate of healthy smokers contained increased levels of IL-1 $\beta$, IL-6, IL-8, IL-10, and TNF- $\alpha$ [133]. In rodent models, acute and chronic cigarette smoke exposure increased levels of TNF- $\alpha$, IL-1 $\beta$, IL-8, and MCP-1, and increased mononuclear cells and neutrophils in the lung [134]. TNF- $\alpha$ may be the crucial factor for cigarette smoke-induced emphysema, since overexpression of TNF- $\alpha$ causes emphysema and alveolar inflammation [135]. Likewise, TNF- $\alpha$ receptor knockout mice were protected against emphysema [136]. Finally, cigarette upregulates MUC5AC expression, amplifying the expression of respiratory mucins and reduce the airflow [137].

\section{CEBPS AND CHRONIC INFLAMMATORY LUNG DISEASES}

C/EBPs: C/EBPs comprise a family of six proteins, $\mathrm{C} / \mathrm{EBP} \alpha, \beta, \delta, \gamma, \varepsilon$ and $\zeta$, which are characterised by two transactivation domains, a basic DNA binding domain and a leucine zipper motif. The latter mediates dimerization between same (homo-dimers) or other C/EBPs (heterodimers) $[138,139]$. $\mathrm{C} / \mathrm{EBPs}$ are pleiotropic proteins involved in inflammation, cell differentiation and tissue remodelling. $\mathrm{C} / \mathrm{EBPs}$ are involved in the fine-tuning of cell differentiation and metabolism. Their ability to control differentiation is achieved trough their interaction with other transcription factors, such as the peroxisome proliferator activated receptor- $\gamma$ (PPAR- $\gamma$ ) in a cell type specific manner [140, 141]. Due to functional redundancy, C/EBP- null mice often fail to yield informative phenotypes [140]. The best studied $\mathrm{C} / \mathrm{EBP}$ family members are $\mathrm{C} / \mathrm{EBP} \alpha$ and $\mathrm{C} / \mathrm{EBP} \beta$.

C/EBPa: $\mathrm{C} / \mathrm{EBP} \alpha$ is a DNA binding transcription factor that binds to the CCAAT box motif present in several gene promoters [142]. The highest level of $\mathrm{C} / \mathrm{EBP} \alpha \mathrm{mRNA}$ are found in differentiated cells of the liver, adipose tissue, the intestine, the lung, and the adrenal gland, as well as in myeloid and placental cells [143]. $\mathrm{C} / \mathrm{EBP} \alpha$ plays a crucial role in cell growth arrest and cell differentiation, showing an expression pattern which is inversely related to proliferation [144]. As reviewed by Johnson et al. [145], initial evidence for the anti-proliferative function of $\mathrm{C} / \mathrm{EBP} \alpha$ came from the activation of a chimeric $\mathrm{C} / \mathrm{EBP} \alpha$-estrogen-receptor (ER) by estrogen-arrested pre-adipocytes in the G0/G1 phase [146]. More recently $\mathrm{C} / \mathrm{EBP} \alpha$ has been implicated in the development of a form of acute myelogenous leukemia (AML1-ETO), where $\mathrm{C} / \mathrm{EBP} \alpha$ expression is suppressed or strongly decreased, leading to leukemogenesis and impaired neutrophil differentiation due to an inhibition of cell cycle exit [147]. In acute myeloid leukemia (AML) the oncogenic fusion proteins BCR-ABL and AML1-MDS1-EVI1 increased calreticulin (CRT) levels, which then inhibited $\mathrm{C} / \mathrm{EBP} \alpha$ translation [148]. In general, the down-regulation of

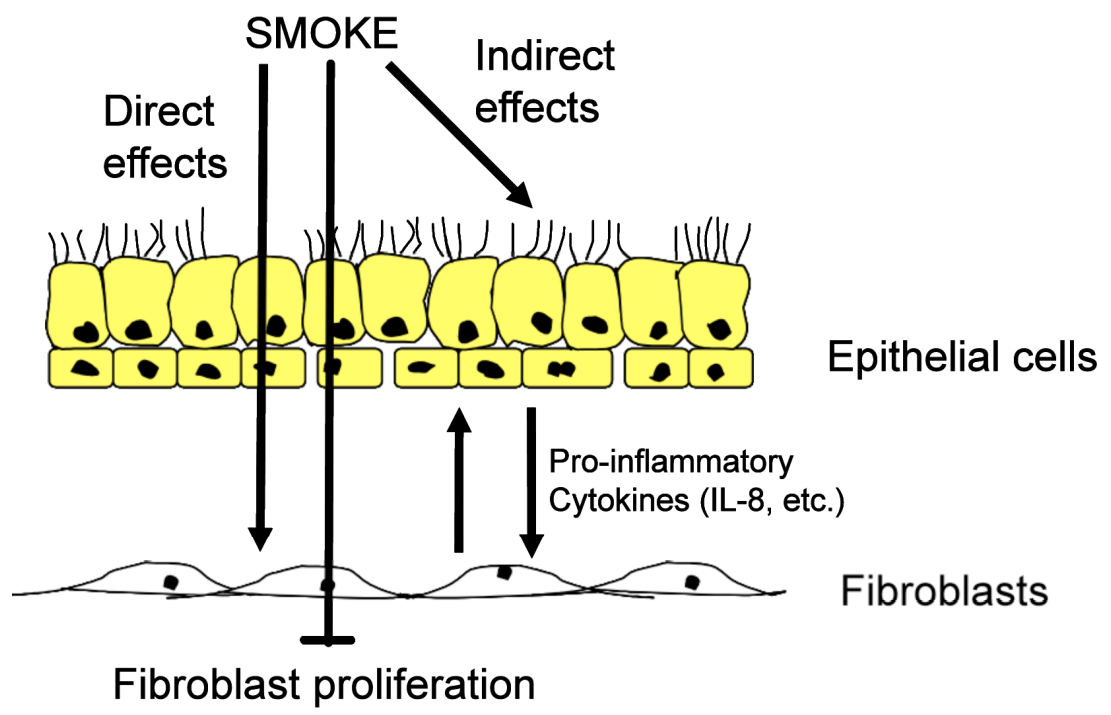

Fig. (2). Effects of cigarette smoke. Cigarette smoke is able to penetrate the airway wall, thereby activating epithelial cells and fibroblast to produce proinflammatory cytokines, in particular interleukin 8 (IL8). In addition, cigarette smokes causes the fibroblasts to stop proliferation. Over time, the net effect may result in a loss of lung tissue. 
$\mathrm{C} / \mathrm{EBP} \alpha$ protein appears crucial in myeloid leukemia development. In the lung, $\mathrm{C} / \mathrm{EBP} \alpha$ is also a master regulator of airway epithelial differentiation and its loss of function as a tumor suppressor leads to non-small lung cancer [149]. $\mathrm{C} / \mathrm{EBP} \alpha$ associates with the cyclin-dependent kinase (CDK) inhibitor p21 [150], which then binds and inhibits the activity of $\mathrm{CDKs}$. $\mathrm{C} / \mathrm{EBP} \alpha$ binds directly to $\mathrm{CDK} 2$ and CDK4 thereby inhibiting them to phosphorylate their substrate [145]. In normal cells, $\mathrm{C} / \mathrm{EBP} \alpha$ forms a complex with the glucocorticoid receptor (GR), which then activates the p21(Waf1/Cip1) promoter [151-153]. Furthermore, $\mathrm{C} / \mathrm{EBP} \alpha$ can directly repress S-phase driving genes either forming a complex with EF2 or binding directly to the CCAAT consensus site in these genes and suppress their transcription [145]. These findings show that $\mathrm{C} / \mathrm{EBP} \alpha$ protein plays an important role in both cell-cycle arrest and cell differentiation. However, $\mathrm{C} / \mathrm{EBP} \alpha$ can also have opposite functions. For instance, in p21-deficient mouse embryo fibroblast $\mathrm{C} / \mathrm{EBP} \alpha$ induced cell-cycle exit [154].

Translation control of $\boldsymbol{C E B P}$ mRNA: In humans, the mRNAs of the $C E B P A$ and $C E B P B$ genes are present ubiquitously and protein levels are predominantly regulated at the translational level. The mRNAs of both genes have specific and highly distinguished regulatory motifs, and several $\mathrm{C} / \mathrm{EBP} \alpha$ proteins are translated from a single $C E B P A$ mRNA by three different so called Kozak sequences [155]. The different $\mathrm{C} / \mathrm{EBP} \alpha$ isoforms retain different parts and functional domains and display opposite functions regarding gene regulation and cell proliferation. The full-length $\mathrm{C} / \mathrm{EBP} \alpha(\mathrm{p} 40 / 42)$ is a transcription, and contains a transactivation domain, while the truncated $\mathrm{C} / \mathrm{EBP} \alpha(\mathrm{p} 30)$ lacks this transactivation activity and counteracts the function of the full-length protein [156-159].

The mechanism of translation control of the CEBPA mRNA is presented in Fig. (3). CEBPA mRNA contains three translation initiation sites (AUG), which are in an optimal Kozak consensus sequence $[155,160]$. The human $C E B P A$ mRNA, therefore, can be translated into three proteins of different size: $42 \mathrm{kD}, 40 \mathrm{kD}$ and $30 \mathrm{kD}$ proteins, respectively. Null-mutations abolishing the expression of the full-length forms [p42, p40] enhanced the expression of the truncated protein (p30) [155]. An additional upstream open reading frame (uORF), which is always out of frame with respect to the $C E B P$ coding frame, translates a small pentapeptide. Mutations in this uORF abolished the translation of the truncated form (p30) and enhanced the expression of the full-length ( $\mathrm{p} 40 / 42)$, demonstrating that the $\mathrm{uORF}$ is essential for differential translation initiation. The organization of the $C E B P B$ mRNA is very similar to that of $C E B P A$ and the same regulatory mechanism generates full length and truncated proteins [155].

Several distinct pathways control the initiation of $C E B P$ mRNA translation: (1) glycogen-synthase kinase 3 (GSK3), (2) phosphoinostitol 3-kinase (PI3K), and (3) mammalian target of rapamaycin (mTOR). The RNA-dependent protein kinase (PKR) is part of the GSK3-pathway and affects translation initiation by phosphorylation-induced inactivation of the rate-limiting translation protein eIF-2, which is part of the ternary eIF2/GTP/Met-tRNA- ${ }^{\text {Met }}$ complex [161]. This facilitates the recognition of the AUG-codon and initiates protein synthesis. In addition to PKR, three more eIF2 kinases exist: (1) haem-regulated inhibitor kinase (HRI), (2) PKR-like endoplasmic-recticulum kinase (PERK) and (3) GCN2 [162]. In PKR mutant cells, eIF-2 cannot be inactivated and the $\mathrm{C} / \mathrm{EBP} \alpha$ expression shifted towards the truncated form. Similarly, activation of the mTOR pathway leads to more truncated proteins [155], as mTOR phosphorylates and inhibits PP2A, which in turn keeps the translation inhibitory 4E-BP1 protein in an active state [163167]. It has been reported that 4E-BP1 inhibits eIF4E activity [168]. In addition, binding of eIF4E to the mRNAcap is the rate-limiting step of the eIF4E complex and of the initiation of translation [169]. Over-expression of eIF4E shifted CEBPA mRNA translation towards the truncated isoform, while the inhibition of $\mathrm{mTOR}$ by rapamycin reduced the expression of the truncated $\mathrm{C} / \mathrm{EBP} \alpha$ isoform [155]. High eIF-2 and eIF-4E activity leads to predominant expression of truncated $\mathrm{C} / \mathrm{EBP} \alpha$ and $\mathrm{C} / \mathrm{EBP} \beta$ proteins.

The $\mathrm{uORF}$ is crucial to modulate the ratio of $\mathrm{C} / \mathrm{EBP} \alpha$ isoforms and thus the re-initiation of translation. When the
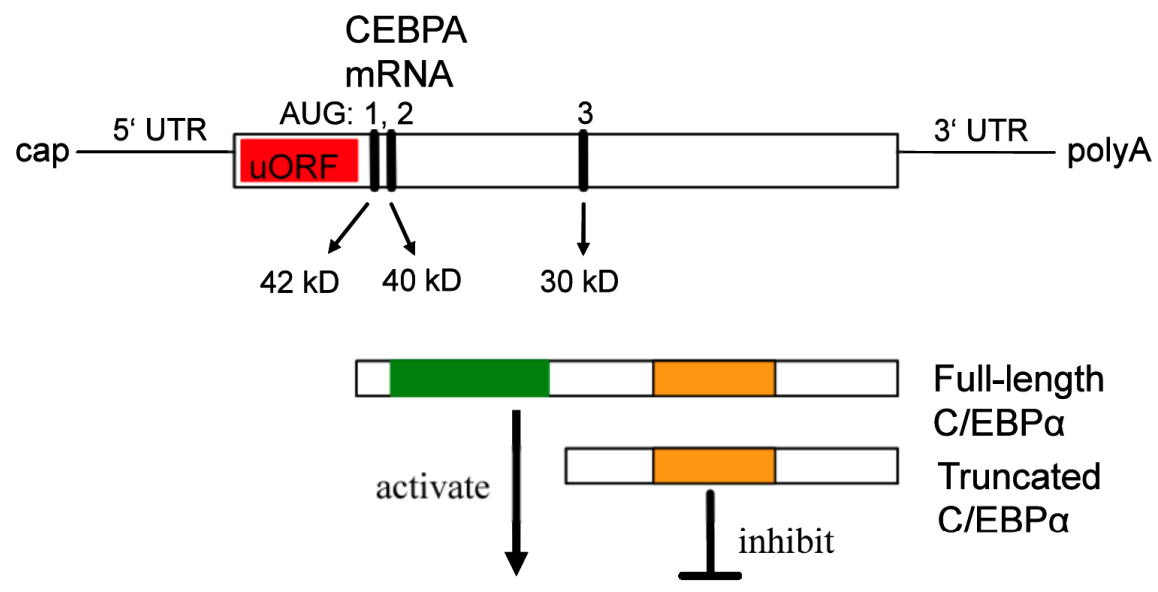

\section{Activation of target genes, proliferation arrest, differentiation}

Fig. (3). Schematic representation of the CEBPA mRNA, the position of the translation start codons (AUG), and the translation products (red: upstream open reading frame; green: transactivation domain; orange: DNA binding domain; uORF: upstream open reading frame). 


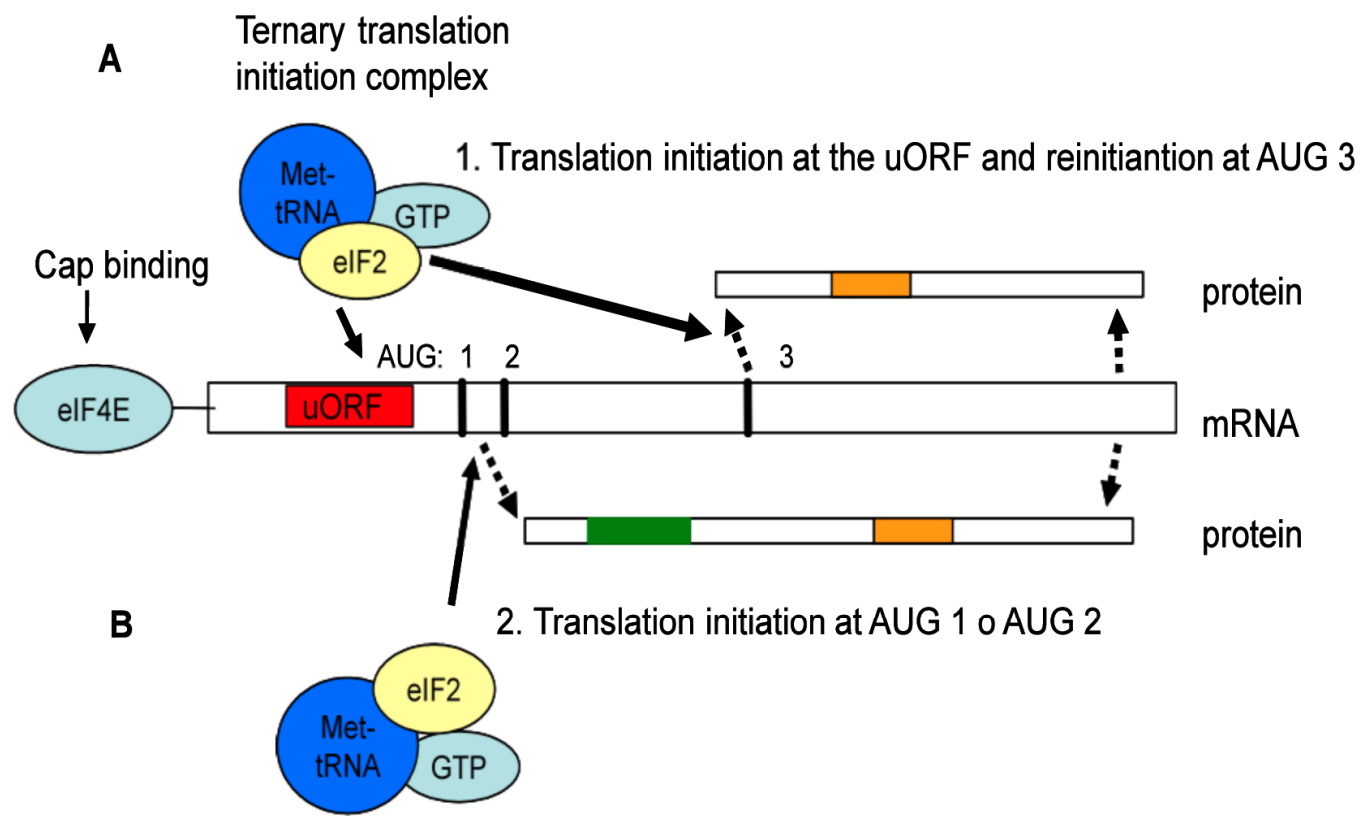

Fig. (4). Schematic representation of the $C E B P A$ mRNA translation mechanism, leading to the formation of the truncated or full-length $\mathrm{C} / \mathrm{EBP} \alpha$ protein. For truncated $\mathrm{C} / \mathrm{EBP} \alpha$ proteins, the translation starts at the $\mathrm{uORF}$ and stops after translation of the uORF. Then it reinitiates at AUG 3, generating the truncated isoform (A). For the generation of the full length C/EBP $\alpha$ the translation starts at the start codon AUG 1 or AUG 2 and reads trough (B). (Red: upstream open reading frame; Green: transactivation domain; Orange: DNA binding domain).

translation activity from the $\mathrm{uORF}$ initiation codon is low, steric hindrance of the ribosomal complex is also low which generates full-length $\mathrm{C} / \mathrm{EBP} \alpha$ proteins, because translation is initiated from the first and second AUG-codon (see Fig. 4). Lack of nutrients or the presence of inhibitory signals, further decreases truncated proteins due to reduced efficiency of translation re-initiation at the third AUG codon [155]. When translation activity from the uORF initiation codon is high, however, steric hindrance is high and the third AUG-codon is the preferred site of translation initiation. This results in an increased level of truncated [p30] proteins $[170,171]$. The efficiency of translation re-initiation depends on the reloading of the eIF2/GTP/Met-tRNA ${ }^{\text {Met }}$ complex, whereas the eIF4E complex is required for efficient scanning and re-initiation after uORF translation $[155,172]$. The rapid shift from truncated to full-length protein allows for a stringently controlled regulation and fine-tuning of cellular response to external stimuli. This is important, because it determines whether cells proliferate or exit the cell cycle and differentiate. The small uORFs is a cis-regulatory mRNA element of translation initiation, that has been found in various regulatory genes, including those for transcription factors SCL/Tall [173] and ATF-4 [174], thrombopoietin (TPO) [175], cyclin CLN3 [176] and beta-Secretase (BACE1) $[177]$.

Finally, CEBPA mRNA translation is reduced by calreticulin-binding to a $C E B P A$ mRNA stem loop formed by a $\mathrm{GC}$ rich motif. Binding of calreticulin to this motif repressed the translation [178]. In adipogenesis, an inverse relationship of $\mathrm{C} / \mathrm{EBP} \alpha$ and calreticulin expression exists and calreticulin promoted adipogenesis by repressing the expression of $\mathrm{C} / \mathrm{EBP} \alpha$ and PPAR $\alpha$ [179]. The opposite also occurs, when the hematopoietic zinc-finger, Hzf, interacts with the 3' un-translated region of the CEBPA mRNA, thereby enhancing the translation [180].
CEBP mRNA translation and disease: The etiologies of several human diseases can be traced back to mutations of genes that encode proteins of the translation control machinery. A wide range of proliferative disorders, including cancers, has been associated with deregulated or faulty mRNA translation [181]. Mutations of the PERK kinase that regulates eIF2 activity cause the WolcottRallison Syndrome (WRS), a form of permanent diabetes [182-184]. Increased levels of eIF4E are found in several cancers $[185,186]$, including colon adenoma and carcinoma [187], breast carcinoma [188, 189], non-Hodgkin's lymphoma [190] and primary bladder cancer [191], and in chronic myeloid leukaemia, the expression of the RNAbinding protein hnRNP is abnormally high. Interestingly, hnRNP binds to the 5' UTR of the CEBPA mRNA thereby inhibiting its translation [192]. In addition, the deregulation of eIF2 is frequently observed in cancer cells $[159,187,190$, 193]. Congenital thrombocythaemia, a disease characterised by sustained proliferation of bone-marrow mega-karyocytes, is also caused by a mutation in the uORF of the cytokine thrombopoietin [174].

Airway remodelling and C/EBPs: In human ASM cells and fibroblasts, $\mathrm{C} / \mathrm{EBP} \alpha$ regulates proliferation trough the induction of the cell cycle inhibitor $\mathrm{p} 21^{\text {Wafl/Cip1 }}$. In normal cells, $\beta$-mimetics and steroids activate $\mathrm{p} 21^{\dot{\mathrm{Waf}} / / \mathrm{Cip} 1}$ via $\mathrm{C} / \mathrm{EBP} \alpha$ forming a complex with the glucocorticoid receptor (GR). In absence or at low levels, the C/EBP $\alpha$ complex with the GR can not be formed in sufficient amounts to activate the $\mathrm{p} 21^{\text {Wafl/Cipl }}$ gene and may explain the increased proliferation of ASM cells. [151-153, 194, 195]. We recently showed that ASM cells of asthma patients have normal levels of CEBPA mRNA, but the translation is impaired leading to a decreased expression of the $\mathrm{C} / \mathrm{EBP} \alpha$ protein [196]. This mechanism operates via the uORF of the CEBPA mRNA [197]. In this respect, it is important to note that in a 
rhesus monkey model, exposure to HDM during the early years of life led to a persistent increase of ASM cells by an unknown mechanism but independent of the immune system [198]. Hence, hyperplasia of ASM cells may be the result of prolonged exposure to HDM allergens. Indeed, we recently observed that HDM extracts significantly reduced $\mathrm{C} / \mathrm{EBP} \alpha$ expression in ASM cells of asthma patients [197]. Interestingly, the reduction operated via the $\mathrm{UORF}$ mechanism, but rather via increased levels of calreticulin. In addition, HDM exposure induced ASM cell proliferation and enhanced the release of IL-6. Furthermore, HDM reduced $\mathrm{C} / \mathrm{EBP} \alpha$ levels via the activation of the PAR-2 receptor. Hence, HDM triggered both protease-dependent and protease-independent mechanisms that regulate $\mathrm{C} / \mathrm{EBP} \alpha$ [197]. These observations indicate a link between deregulated $\mathrm{C} / \mathrm{EBP} \alpha$ translation and in vitro hyperplasia of ASM cells and inflammation. The mechanism by which an impaired translation of the $C E B P A$ mRNA may lead to the characteristics of an asthmatic airway is presented in Fig. (5).

Airway hyper-responsiveness and C/EBPs: Airway biopsy specimens of asthma patients exhibited a significant increase in the contractile properties [199, 200]. Even single ASM cells demonstrated increased intrinsic contractile properties, which coincided with enhanced expression levels of myosin light-chain kinase messenger RNA in ASM cells of asthma patients [199]. Such an increase might account for the increased velocity of muscle cell shortening, since myosin light-chain kinase (MLCK) phosphorylates the regulatory light chain of myosin and regulates the rate of cross-bridge cycling, and therefore of the contractile properties of ASM cells. Although the promoter that regulates the expression of this kinase contains several $\mathrm{C} / \mathrm{EBP}$ binding sites, the effect of $\mathrm{C} / \mathrm{EBP}$ binding in this region is currently unknown [201].

Airway inflammation and C/EBPs: $N F \kappa B$ is an important proinflammatory transcription factor required for the expression of cytokines, adhesion molecules, chemokines and growth factors $[74,202]$. Interestingly, $\mathrm{C} / \mathrm{EBP} \alpha$ has the potential to silence this inflammatory response through interference with $\mathrm{NF} \kappa \mathrm{B}[34,35]$. The expression of many cytokines [203] and TARC [202] depends on NFkB and/or $\mathrm{C} / \mathrm{EBP}$ binding sites in their promoters. Because $\mathrm{C} / \mathrm{EBP} \alpha$ (p40/42) is mainly a negative regulator of gene expression, a diminished expression of it may initiate airway inflammation through the release of proinflammatory mediators into the airway. The asthma-associated cytokine IL-4 blocks C/EBP $\alpha$ expression [204], hence sustaining airway inflammation. The observation that ASM cells of asthma patients produce less $\mathrm{PGE}_{2}$ than those from normals, suggests that $\mathrm{PGE}_{2}$ may also sustain a Th2-like inflammation. $\mathrm{PGE}_{2}$ is a potent inhibitor of proliferation and cell activity. Binding of $\mathrm{PGE}_{2}$ to its receptor generates cyclic adenosine mono phosphate (AMP), which counteracts the production of many proinflammatory cytokines and chemokines. Th2-like cytokines, in particular IL-4 and IL-5, are less susceptible to the inhibitory effect of cyclic AMP than Th1-like cytokines [205]. Intriguingly, the expression of the main regulator of $\mathrm{PGE}_{2}$ production (COX2) critically depends on C/EBPs. Here, we also do not know the effects of the various C/EBP isoforms [206].

COPD and C/EBPs: The role of $C E B P$ genes in the development of COPD is less clear. In lung epithelial cells of COPD patients, DNA-binding C/EBP $\beta$ levels are decreased relative to cells of 'healthy smokers' and might render the epithelium resistant to efficient regeneration [207]. In primary human lung fibroblasts, cigarette smoke regulated both $\mathrm{C} / \mathrm{EBP} \alpha$ and $\mathrm{C} / \mathrm{EBP} \beta$ via two distinct translational control pathways [197]. In the absence of serum, cigarette smoke induced full-length $\mathrm{C} / \mathrm{EBP} \alpha$ and $-\beta$ proteins via the uORF mechanism, which coincided with decreased proliferation and increased expression of IL-8 (which is $\mathrm{C} / \mathrm{EBP}$ controlled) [208]. In the presence of FCS, cigarette smoke decreased $\mathrm{C} / \mathrm{EBP} \alpha$ and $-\beta$ via an induction of hnRNP $\mathrm{E} 2$. Here, the anti-proliferative role of full-length $\mathrm{C} / \mathrm{EBP} \alpha$ proteins may explain the reduced proliferation of fibroblasts,

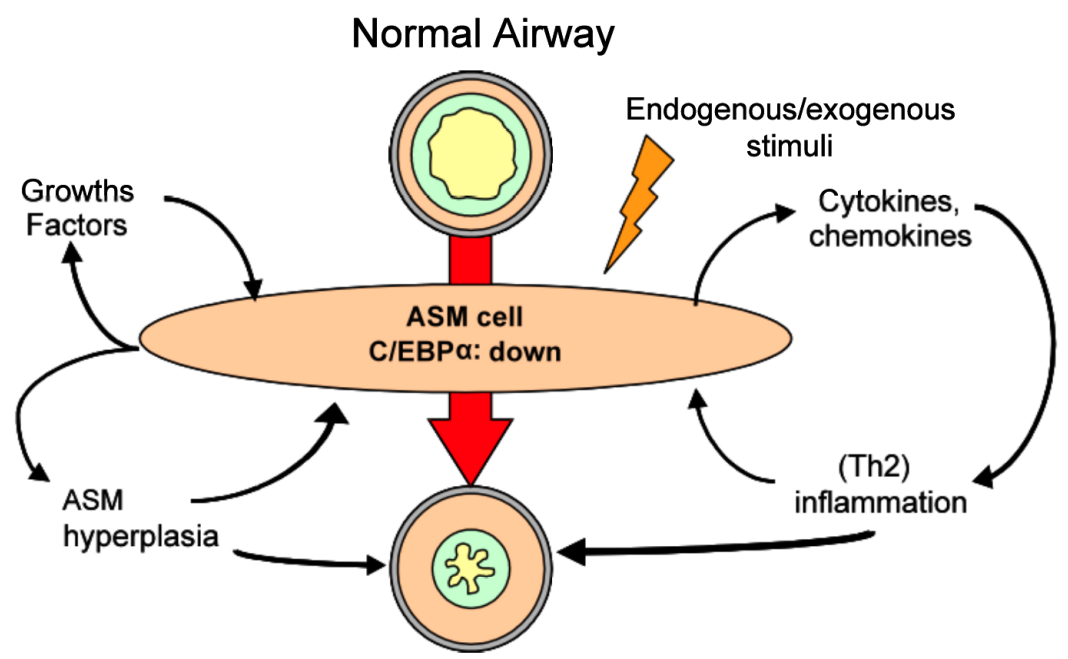

\section{Asthmatic Airway}

Fig. (5). Model with the proposed central role of the airway smooth muscle (ASM) cell in airway inflammation and remodeling. Due to predisposition and/or environmental stimuli, ASM cells of patients with asthma express decreased levels of the C/EBP $\alpha$. [Adapted from Borger P, Tamm M, Black JL, Roth M., Asthma: is it due to an abnormal airway smooth muscle cell? Am J Respir Crit Care Med. 2006 Aug 15; 174(4): 367-72]. 
hence providing a basis to understand the destruction of the tissue and the increased airway remodelling observed in later stages of COPD. In addition, increased full-length C/EBP $\beta$ levels may result in reducing the elastin levels in alveoli, because $\mathrm{C} / \mathrm{EBP} \beta$ is a negative regulator of elastin transcription [209].

\section{C/EBPs and Therapy}

The treatment of the increased bulk of ASM cells as observed in the lungs of asthmatic patients may be through the modulation of the $\mathrm{C} / \mathrm{EBP} \alpha$ translation. This would require novel therapeutical strategies that target mainly the signaling pathways regulating the translation control at the uORF, e.g. the mTOR pathway. Alternatively, lithium chloride has been shown to prevent the degradation of $\mathrm{C} / \mathrm{EBP} \alpha$ protein and might be tested as a candidate drug to counteract airway wall remodelling in asthma [210]. Similar strategies might be envisioned in the treatment of the remodeling processes in the lung of COPD patients, but with the focus on $\mathrm{C} / \mathrm{EBP} \delta$ [196].

\section{GENERAL CONCLUSIONS AND OUTLOOK}

The pathologies of asthma and COPD are genetically predisposed, but the environment plays a crucial role for the initiation and progression of these diseases. Impaired translation of the cell cycle regulators of the C/EBP family may play a significant role in the pathogenesis of these lung diseases. Here we argued that asthma may stem from an impaired translation of $C E B P A$ mRNA. A direct interaction of ASM cells of asthma patients with HDM may be a key event that chronically reduces $\mathrm{C} / \mathrm{EBP} \alpha$ protein levels. The lack of $\mathrm{C} / \mathrm{EBP} \alpha$ protein speeds up cell proliferation and stimulates the release of pro-inflammatory cytokines. The results are an increased bulk of ASM cells and airway inflammation, two key pathologies in asthma. Regarding the development of COPD, cigarette smoke-induced aberrant translational control of $C E B P A$ and $C E B P B$ mRNAs may be the key to understand and treat COPD pathology. Today, no effective therapy for COPD is available and strategies to prevent remodelling parameters are scant. Restoring the balanced expression of both $\mathrm{C} / \mathrm{EBP} \alpha$ and $\mathrm{C} / \mathrm{EBP} \beta$ by intervention at the level of translation control may be beneficial for both asthma and COPD patients.

\section{ACKNOWLEDGEMENT OF FUNDING}

Swiss National Science Foundation (SNSF 320030124905 and SNSF 310030-133109).

\section{CONFLICT OF INTEREST}

None Declared.

\section{REFERENCES}

[1] Diamant Z, Boot JD, Virchow JC. Summing up 100 years of asthma. Respir Med 2007; 101: 378-88

[2] Global Initiative for asthma (GINA), Report, 2006. Available at: http://www.ginasthma.org/Guidelineitem.asp?11 $=2 \& 12=1 \&$ intld $=1$ 558

[3] Holgate ST. Pathogenesis of asthma. Clin Exp Allergy 2008; 38: 872-97.

[4] Reed CE. The natural history of asthma. J Allergy Clin Immunol 2006; 118: 543-8.

[5] [No Author Listed]. Asthma: still more questions than answer. Lancer 2008; 372: 1009.
[6] Holloway JW, Beghé B, Holgate ST. The genetic basis of atopic asthma. Clin Exp Allergy 1999; 29: 1023-32.

[7] Wiesch DG, Meyers DA, Bleecker ER. Genetics of asthma. J Allergy Clin Immunol 1999; 104: 895-901.

[8] Strachan DP. Hay fever, hygiene, and household size. BMJ 1989; 299: 1259-60.

[9] Postma DS, Bleecker ER, Amelung PJ, et al. Genetic susceptibility to asthma--bronchial hyperresponsiveness coinherited with a major gene for atopy. N Engl J Med 1995; 333: 894-900.

[10] Laprise C, Sladek R, Ponton A, Bernier M, Hudson TJ, Laviolette M. Functional classes of bronchial mucosa genes that are differentially expressed in asthma. BMC Genomics 2004; 5: 21.

[11] Horwood LJ, Fergusson DM, Shannon FT. Social and familial factors in the development of early childhood asthma. Pediatrics 1985; 75: 859-68.

[12] Wahn U, Lau S, Bergmann R, et al. Indoor allergen exposure is a risk factor for sensitization during the first three years of life. $\mathrm{J}$ Allergy Clin Immunol 1997; 99: 763-9.

[13] Sporik R, Holgate ST, Platts-Mills TA, Cogswell JJ. Exposure to house-dust mite allergen (Der p I) and the development of asthma in childhood. A prospective study. N Engl J Med 1990; 323: 502-7.

[14] Hogaboam CM, Carpenter KJ, Schuh JM, Buckland KF. Aspergillus and asthma--any link? Med Mycol 2005; 43: S197-202.

[15] Huss K, Adkinson NF Jr, Eggleston PA, Dawson C, Van Natta ML, Hamilton RG. House dust mite and cockroach exposure are strong risk factors for positive allergy skin test responses in the Childhood Asthma Management Program. J Allergy Clin Immunol 2001; 107: 48-54.

[16] Sears MR, Greene JM, Willan AR, et al. A longitudinal, population-based, cohort study of childhood asthma followed to adulthood. N Engl J Med 2003; 349: 1414-22.

[17] Sporik R, Ingram JM, Price W, Sussman JH, Honsinger RW, Platts-Mills TA. Association of asthma with serum IgE and skin test reactivity to allergens among children living at high altitude. Tickling the dragon's breath. Am J Respir Crit Care Med 1995; 151: 1388-92.

[18] Charpin D, Birnbaum J, Haddi E, et al. Altitude and allergy to house-dust mites. A paradigm of the influence of environmental exposure on allergic sensitization. Am Rev Respir Dis. 1991; 143: 983-6.

[19] Gern JE, Reardon CL, Hoffjan S, et al. Effects of dog ownership and genotype on immune development and atopy in infancy. $J$ Allergy Clin Immunol 2004; 113: 307-14.

[20] Celedón JC, Litonjua AA, Ryan L, Platts-Mills T, Weiss ST, Gold DR. Exposure to cat allergen, maternal history of asthma, and wheezing in first 5 years of life. Lancet 2002; 360: 78.

[21] Braun-Fahrländer C. Environmental exposure to endotoxin and other microbial products and the decreased risk of childhood atopy: evaluating developments since April 2002. Curr Opin Allergy Clin Immunol 2003; 3: 325-9.

[22] Sigurs N, Bjarnason R, Sigurbergsson F, Kjellman B. Respiratory syncytial virus bronchiolitis in infancy is an important risk factor for asthma and allergy at age 7. Am J Respir Crit Care Med 2000; 161: 1501-7.

[23] Gern JE, Busse WW. Relationship of viral infections to wheezing illnesses and asthma. Nat Rev Immunol 2002; 2: 132-8.

[24] Stein RT, Sherrill D, Morgan WJ, et al. Respiratory syncytial virus in early life and risk of wheeze and allergy by age 13 years. Lancet 1999; 354: 541-5.

[25] de Meer G, Janssen NA, Brunekreef B. Early childhood environment related to microbial exposure and the occurrence of atopic disease at school age. Allergy 2005; 60: 619-25.

[26] Dykewicz MS. Occupational asthma: current concepts in pathogenesis, diagnosis, and management. J Allergy Clin Immunol 2009; 123: 519-28.

[27] Malo JL, Lemière C, Gautrin D, Labrecque M. Occupational asthma Curr Opin Pulm Med 2004; 10: 57-61.

[28] Venables KM, Chan-Yeung M. Occupational asthma. Lancet 1997; 349: 1465-9.

[29] Sastre J, Vandenplas O, Park HS. Pathogenesis of occupational asthma. Eur Respir J 2003; 22: 364-73.

[30] Tager IB. The effects of second-hand and direct exposure to tobacco smoke on asthma and lung function in adolescence. Paediatr Respir Rev 2008; 9: 29-37. 
[31] Chalmers GW, Macleod KJ, Little SA, Thomson LJ, McSharry CP, Thomson NC. Influence of cigarette smoking on inhaled corticosteroid treatment in mild asthma. Thorax 2002; 57: 226-30.

[32] Nafstad P, Kongerud J, Botten G, Hagen JA, Jaakkola JJ. The role of passive smoking in the development of bronchial obstruction during the first 2 years of life. Epidemiology 1997; 8: 293-7.

[33] Kim H, Bernstein JA. Air pollution and allergic disease. Curr Allergy Asthma Rep 2009; 9: 128-33.

[34] Belanger K, Triche EW. Indoor combustion and asthma. Immunol Allergy Clin North Am 2008; 28: 507-19.

[35] Gauderman WJ, Avol E, Gilliland F, et al. The effect of air pollution on lung development from 10 to 18 years of age. $\mathrm{N}$ Engl $\mathrm{J}$ Med 2004; 351: 1057-67.

[36] Devereux G, Seaton A. Diet as a risk factor for atopy and asthma. J Allergy Clin Immunol 2005; 115: 1109-17.

[37] Friedman NJ, Zeiger RS. The role of breast-feeding in the development of allergies and asthma. J Allergy Clin Immunol 2005; 115: 1238-48.

[38] Faniran AO, Peat JK, Woolcock AJ. Prevalence of atopy, asthma symptoms and diagnosis, and the management of asthma: comparison of an affluent and a non-affluent country. Thorax 1999; 54: 606-10.

[39] Roth M, Black JL. An imbalance in C/EBPs and increased mitochondrial activity in asthmatic airway smooth muscle cells: novel targets in asthma therapy? Br J Pharmacol 2009; 157: 33441.

[40] Oryszczyn MP, Bouzigon E, Maccario J, et al. Interrelationships of quantitative asthma-related phenotypes in the Epidemiological Study on the Genetics and Environment of Asthma, Bronchial Hyperresponsiveness, and Atopy. J Allergy Clin Immunol 2007; 119: 57-63.

[41] Kaur D, Saunders R, Berger P, et al. Airway smooth muscle and mast cell-derived $\mathrm{CC}$ chemokine ligand 19 mediate airway smooth muscle migration in asthma. Am J Respir Crit Care Med 2006; 174: $1179-88$

[42] Sutcliffe A, Kaur D, Page S, et al. Mast cell migration to Th2 stimulated airway smooth muscle from asthmatics. Thorax 2006; 61: 657-62.

[43] Woodman L, Sutcliffe A, Kaur D, et al. Chemokine concentrations and mast cell chemotactic activity in BAL fluid in patients with eosinophilic bronchitis and asthma, and in normal control subjects. Chest 2006; 130: 371-8

[44] Scott K, Bradding P. Human mast cell chemokines receptors: implications for mast cell tissue localization in asthma. Clin Exp Allergy 2005; 35: 693-7.

[45] Schmidlin F, Amadesi S, Vidil R, et al. Expression and function of proteinase-activated receptor 2 in human bronchial smooth muscle. Am J Respir Crit Care Med 2001; 164: 1276-81.

[46] Beasley R, Roche WR, Roberts JA, Holgate ST. Cellular events in the bronchi in mild asthma and after bronchial provocation. Am Rev Respir Dis 1989; 139: 806-17.

[47] Jeffery PK, Wardlaw AJ, Nelson FC, Collins JV, Kay AB. Bronchial biopsies in asthma: an ultrastructural, quantitative study and correlation with hyperreactivity. Am Rev Respir Dis 1989; 140: $1745-53$

[48] Bucchieri F, Puddicombe SM, Lordan JL, et al. Asthmatic bronchial epithelium is more susceptible to oxidant-induced apoptosis. Am J Respir Cell Mol Biol 2002; 27: 179-85.

[49] Kicic A, Sutanto EN, Stevens PT, Knigh, DA, Stick SM. Intrinsic biochemical and functional differences in bronchial epithelial cells of children with asthma. Am J Respir Crit Care Med 2006; 174: 1110-18.

[50] Barbato A, Turato G, Baraldo S, et al. Epithelial damage and angiogenesis in the airways of children with asthma. Am J Respir Crit Care Med 2006; 174: 975-81.

[51] Puddicombe SM, Polosa R, Richter A, et al. Involvement of the epidermal growth factor receptor in epithelial repair in asthma. FASEB J 2000; 14: 1362-74

[52] Huang J, Olivenstein R, Tah, R, Hamid Q, Ludwig M. Enhanced proteoglycan deposition in the airway wall of atopic asthmatics. Am J Respir Crit Care Med 1999; 160: 725-9.

[53] Vignola AM, Kips J, Bousquet J. Tissue remodeling as a feature of persistent asthma. J Allergy Clin Immunol 2000; 105: 1041-53.
[54] Akers IA, Parsons M, Hill MR, et al. Mast cell tryptase stimulates human lung fibroblast proliferation via protease-activated receptor2. Am J Physiol Cell Mol Physiol 2000; 278: L193-201.

[55] Ebina M, Takahashi T, Chiba T, Motomiya M. Cellular hypertrophy and hyperplasia of airway smooth muscles underlying bronchial asthma. A 3-D morphometric study. Am Rev Respir Dis 1993; 148: 720-6.

[56] Huber H, Koesser K. The pathology of bronchial asthma. Arch Intern Med 1922; 30: 689-760.

[57] Cutz E, Levison H, Cooper DM. Ultrastructure of airways in children with asthma. Histopathology 1978; 2: 407-21.

[58] Cokugras H, Akcakaya N, Seckin I, Camcioglu Y, Sarimurat N, Aksoy F. Ultrastructural examination of bronchial biopsy specimens from children with moderate asthma. Thorax 2001; 56: 25-9.

[59] Jeffery P. Inflammation and remodeling in the adult and child with asthma. Pediatr Pulmonol 2001; 21:3-16.

[60] McKay KO, Hogg JC. The contribution of airway structure to early childhood asthma. Med J Aust 2002; 177: S45-7.

[61] Jenkins HA, Cool C, Szefler SJ, et al. Histopathology of severe childhood asthma: a case series. Chest 2003; 124: 32-41.

[62] Payne DN, Rogers AV, Adelroth E, et al. Early thickening of the reticular basement membrane in children with difficult asthma. Am J Respir Crit Care Med 2003; 167: 78-82.

[63] Avdalovic M, Gershwin LJ, Joad JP, et al. Asthma/allergic airways disease: does postnatal exposure to environmental toxicants promote airway pathobiology? Toxicol Pathol 2007; 35: 97-110.

[64] Borger P, Tamm M, Black JL, Roth M. Asthma: is it due to an abnormal airway smooth muscle cell? Am J Respir Crit Care Med 2006; 174: 367-72.

[65] Sihra BS, Kon OM, Durham SR, Walker S, Barnes NC, Kay AB. Effect of cyclosporin A on the allergen-induced late asthmatic reaction. Thorax 1997; 52: 447-52.

[66] Khan LN, Kon OM, Macfarlane AJ, et al. Attenuation of the allergen-induced late asthmatic reaction by cyclosporin $\mathrm{A}$ is associated with inhibition of bronchial eosinophils, interleukin-5, granulocyte macrophage colony-stimulating factor, and eotaxin. Am J Respir Crit Care Med 2000; 162: 1377-82.

[67] Leckie MJ, ten Brinke A, Khan J, et al. Effects of an interleukin-5 blocking monoclonal antibody on eosinophilic airway hyperresponsiveness and the late asthmatic response. Lancet 2000; 356: 2144-8.

[68] McCallister JW. Reslizumab and eosinophilic asthma: one step closer to phenotype-directed therapy? Am J Respir Crit Care Med 2011; 184(10): 1096-7

[69] Cox G, Thomson NC, Rubin AS, et al. Asthma Control during the Year after Bronchial Thermoplasty. N Engl J Med 2007; 356: 1327-37.

[70] Hakonarson H, Grunstein MM. Autocrine regulation of airway smooth muscle responsiveness. Respir Physiol Neurobiol 2003; 137: 263-76.

[71] McKay S, Sharma HS. Autocrine regulation of asthmatic airway inflammation: role of the airway smooth muscle. Respir Res 2002; 3: 11

[72] Kahan BD. Cyclosporine. N Engl J Med 1989; 321.

[73] Sano T, Nakamura Y, Matsunaga Y, et al. FK506 and cyclosporin A inhibit granulocyte/macrophage colony-stimulating factor production by mononuclear cells in asthma. Eur Respir J 1995; 8: 1473-8

[74] Faffe DS, Whitehead T, Moore PE, et al. IL-13 and IL-4 promote TARC release in human airway smooth muscle cells: role for IL-4 genotype. Am J Physiol Lung Cell Mol Physiol 2003; 285: L907.

[75] Johnson PR, Roth M, Tamm M, et al. Airway smooth muscle cell proliferation is increased in asthma. Am J Respir Crit Care Med 2001; 164: 474-7.

[76] Burgess JK, Carlin S, Pack RA, et al. Detection and characterization of OX40 ligand expression in human airway smooth muscle cells: a possible role in asthma? J Allergy Clin Immunol 2004; 113: 683-9.

[77] Borger P, Miglino N, Baraket M, Black JL, Tamm M, Roth M. Impaired translation of CCAAT/enhancer binding protein alpha mRNA in bronchial smooth muscle cells of asthmatic patients. Allergy Clin Immunol 2009; 123: 639-45. 
[78] Global Initiative for COPD. Gold report 2008. http://www.gol dcopd.org/Guidelineitem.asp?11=2\&12=1\&intId=2005.

[79] Buist AS, McBurnie MA, Vollmer WM, et al. International variation in the prevalence of COPD (the BOLD Study): a population-based prevalence study. Lancet 2007; 370: 741-50.

[80] Lopez AD, Murray CC. The global burden of disease, 1990-2020. Nat Med 1998; 4: 1241-3.

[81] Rabe KF, Hurd S, Anzueto A, et al. Global strategy for the diagnosis, management, and prevention of chronic obstructive pulmonary disease: GOLD executive summary. Am J Respir Crit Care Med 2007; 176: 532-55.

[82] Ito K, Barnes PJ. COPD as a disease of accelerated lung aging. Chest 2009; 135: 173-80.

[83] Fullerton DG, Bruce N, Gordon S. Indoor air pollution from biomass fuel smoke is a major health concern in the developing world. Trans R Soc Trop Med Hyg 2008; 102(9): 843-51.

[84] Mayer AS, Newman LS. Genetic and environmental modulation of chronic obstructive pulmonary disease. Respir Physiol 2001; 128: 3-11.

[85] Givelber RJ, Couropmitree NN, Gottlieb DJ, et al. Segregation analysis of pulmonary function among families in the Framingham Study. Am J Respir Crit Care Med 1998; 157: 1445-51.

[86] Redline S, Tishler PV, Lewitter FI, Tager IB, Munoz A, Speizer FE. Assessment of genetic and nongenetic influences on pulmonary function. A twin study. Am Rev Respir Dis 1987; 135: 217-22.

[87] Stoller JK, Aboussouan LS. Alpha1-antitrypsin deficiency. Lancet 2005; 365(9478): 2225-36.

[88] Van Diemen C. GSTM1 and GSTT1 null alleles are risk factors for excess lung function decline: a longitudinalcohort study of the general population. Genetics of lung function decline and COPD development. Thesis University of Groningen. Gildeprint, Enschede 2007, 125-135. ISBN: 978-90-367-3329-3328,

[89] Gosman MME, Boezen HM, Van Diemen CC, et al. A disintegrin and metalloprotease 33 and chronic obstructive pulmonary disease pathophysiology. Thorax 2007; 62: 242-7.

[90] Van Diemen CC, Postma DS, Vonk JM, Bruinenberg M, Nolte IM, Boezen HM. Decorin and TGF- $\beta_{1}$ polymorphisms and development of COPD in a general population. Respir Res 2006; 7: 89.

[91] Trupin L, Earnest G, San Pedro M, et al. The occupational burden of chronic obstructive pulmonary disease. Eur Respir J 2003; 22: 462-9.

[92] Blanc PD, Eisner MD, Earnest G, et al. Further exploration of the links between occupational exposure and chronic obstructive pulmonary disease. J Occup Environ Med 2009; 51: 804-10.

[93] Matheson MC, Benke G, Raven J, et al. Biological dust exposure in the workplace is a risk factor for chronic obstructive pulmonary disease. Thorax 2005; 60: 645-51.

[94] Hnizdo E, Sullivan PA, Bang KM, Wagner G. Association between chronic obstructive pulmonary disease and employment by industry and occupation in the US population: a study of data from the Third National Health and Nutrition Examination Survey. Am J Epidemiol 2002; 156: 738-46.

[95] Retamales I, Elliott WM, Meshi B, et al. Amplification of inflammation in emphysema and its association with latent adenoviral infection. Am J Respir Crit Care Med 2001; 164: 46973.

[96] Barker DJ, Godfrey KM, Fall C, Osmond C, Winter PD, Shaheen SO. Relation of birth weight and childhood respiratory infection to adult lung function and death from chronic obstructive airways disease. BMJ 1991; 303: 671-5.

[97] Shaheen SO, Barker DJ, Shiell AW, Crocker FJ, Wield GA, Holgate ST. The relationship between pneumonia in early childhood and impaired lung function in late adult life. Am J Respir Crit Care Med 1994; 149: 616-9.

[98] Prescott E, Lange P, Vestbo J. Socioeconomic status, lung function and admission to hospital for COPD: results from the Copenhagen City Heart Study. Eur Respir J 1999; 13: 1109-14.

[99] Silva GE, Sherrill DL, Guerra S, Barbee RA. Asthma as a risk factor for COPD in a longitudinal study. Chest 2004; 126: 59-65.

[100] Cosio MG, Saetta M, Agusti A. Immunologic aspects of chronic obstructive pulmonary disease. N Engl J Med 2009; 360: 2445-54.

[101] Di Stefano A, Capelli A, Lusuardi M, et al. Severity of airflow limitation is associated with severity of airway inflammation in smokers. Am J Respir Crit Care Med 1998; 158: 1277-85.
[102] Fabbri LM, Romagnoli M, Corbetta L, et al. Differences in airway inflammation in patients with fixed airflow obstruction due to asthma or chronic obstructive pulmonary disease. Am J Respir Crit Care Alveolar Med 2003; 167: 418-24.

[103] Barnes P. Alveolar macrophages as orchestrators of COPD. J COPD 2004; 1: 59-70.

[104] Saetta M, Baraldo S, Corbino L. CD8+ve cells in the lungs of smokers with chronic obstructive pulmonary disease. Am J Respir Crit Care Med 1999; 160: 711-7.

[105] Pesci A, Balbi B, Majori M, et al. Inflammatory cells and mediators in bronchial lavage of patients with chronic obstructive pulmonary disease. Eur Respir J 1998; 12: 380-6.

[106] Barnes PJ. Mechanisms in COPD: differences from asthma. Chest 2000; 117: 10S-4S.

[107] Saetta M, Turato G, Maestrelli P, Mapp CE, Fabbri LM. Cellular and structural bases of chronic obstructive pulmonary disease. Am J Respir Crit Care Med 2001; 163: 1304-9.

[108] Plantier L, Boczkowski J, Crestani B. Defect of alveolar regeneration in pulmonary emphysema: role of lung fibroblasts. Int J Chron Obstruct Pulmon Dis 2007; 2: 463-9.

[109] Togo S, Holz O, Liu X, et al. Lung fibroblast repair functions in patients with chronic obstructive pulmonary disease are altered by multiple mechanisms. Am J Respir Crit Care Med 2008; 178: 24860 .

[110] Hogg JC, Macklem PT, Thurlbeck WM. Site and nature of airway obstruction in chronic obstructive lung disease. N Engl $\mathrm{J}$ Med 1968; 278: 1355-60.

[111] Cosio M, Ghezzo H, Hogg JC, et al. The relations between structural changes in small airways and pulmonary-function tests. N Engl J Med 1978; 298: 1277-81.

[112] Niewoehner DE, Kleinerman J, Rice DB. Pathologic changes in the peripheral airways of young cigarette smokers. N Engl J Med 1974; 291: 755-8.

[113] Gelb AF, Hogg JC, Müller NL, et al. Contribution of emphysema and small airways in COPD. Chest 1996; 109: 353-9.

[114] Hogg JC, Chu F, Utokaparch S, et al. The nature of small-airway obstruction in chronic obstructive pulmonary disease. N Engl J Med 2004; 350: 2645-53.

[115] De Boer WI, van Schadewijk A, Sont JK, et al. Transforming growth factor beta1 and recruitment of macrophages and mast cells in airways in chronic obstructive pulmonary disease. Am J Respir Crit Care Med 1998; 158: 1951-7.

[116] Takizawa H, Tanaka M, Takami K, et al. Increased Expression of Transforming Growth Factor-beta 1 in Small Airway Epithelium from Tobacco Smokers and Patients with Chronic Obstructive Pulmonary Disease (COPD). Am J Respir Crit Care Med 2001; 163: 1476-83.

[117] Ihn H. Pathogenesis of fibrosis: role of TGF-b \& CTGF. Curr Opin Rheumatol 2002; 14: 681-5.

[118] Chen G, Grotendorst G, Eichholtz T, Khalil N. GM-CSF increases airway smooth muscle cell connective tissue expression by inducing TGF-beta receptors. Am J Physiol Lung Cell Mol Physiol 2003; 284: L548-56.

[119] Saetta M, Ghezzo H, Kim WD, et al. Loss of alveolar attachments in smokers: an early morphometric correlate of lung function impairment. Am Rev Respir Dis 1985; 132: 894-900.

[120] Daheshia M. Therapeutic inhibition of matrix metalloproteinases for the treatment of chronic obstructive pulmonary disease (COPD). Curr Med Res Opin 2005; 21: 587-94.

[121] Srivastava PK, Dastidar SG, Ray A. Chronic obstructive pulmonary disease: role of matrix metalloproteases and future challenges of drug therapy. Expert Opin Investig Drugs 2007; 16: 1069-78.

[122] Demedts IK, Morel-Montero A, Lebecque S, et al. Elevated MMP12 protein levels in induced sputum from patients with COPD Thorax 2006; 61: 196-201.

[123] Hoshino Y, Mio T, Nagai S, Miki H, Ito I, Izumi T. Cytotoxic effects of cigarette smoke extract on an alveolar type II cell-derived cell line. Am J Physiol: Lung Cell Mol Physiol 2001; 281: 509516.

[124] Ishii T, Matsuse T, Igarashi H, Masuda M, Teramoto S, Ouchi, Y. Tobacco smoke reduces viability in human lung fibroblasts: Protective effect of glutathione S-transferase P1. Am J Physiol: Lung Cell Mol Physiol 2001; 280: 1189-95.

[125] MacNee W. Oxidative stress and lung inflammation in airways disease. Eur J Pharmacol 2001; 429: 195-207. 
[126] Bernhard D, Huck CW, Jakschitz T, et al. Development and evaluation of an in vitro model for the analysis of cigarette smoke effects on cultured cells and tissues. J Pharmacol Toxicol Methods 2004; 50: 45-51.

[127] Rennard SI, Togo S, Holz O. Cigarette smoke inhibits alveolar repair: a mechanism for the development of emphysema. Proc Am Thorac Soc 2006; 3: 703-8.

[128] Sato E, Koyama S, Takamizawa A, et al. Smoke extract stimulates lung fibroblasts to release neutrophil and monocyte chemotactic activities. Am J Physiol 1999; 277: L1149-57.

[129] Tuder RM, Voelkel NF. Pathology of chronic bronchitis and emphysema. In: Voelkel NF, MacNee W, Eds. Chronic Obstructive Lung Disease. Montreal, Canada: Dekker 2001; pp. 90-113.

[130] Wright JL, Hobson J, Wiggs BR, Hogg JC. Comparison of inflammatory cells in bronchoalveolar fluid with those in the lumen and tissue peripheral airways and alveolar airspace. Lung 1988; 166: $75-83$.

[131] MacNee W, Wiggs B, Belzberg AS, Hogg JC. The effect of cigarette smoking on neutrophil kinetics in human lungs. N Engl J Med 1989; 321: 924-8.

[132] Churg A, Wang RD, Tai H, et al. Macrophage metalloelastase mediates acute cigarette smoke-induced inflammation via tumor necrosis factor-alpha release. Am J Respir Crit Care Med 2003; 167: 1083-9.

[133] Gessner C, Scheibe R, Wotzel M, et al. Exhaled breath condensate cytokine patterns in chronic obstructive pulmonary disease. Respir Med 2005; 99: 1229-40.

[134] Kubo S, Kobayashi M, Masunaga Y, et al. Cytokine and chemokine expression in cigarette smoke-induced lung injury in guinea pigs. Eur Respir J 2005; 26: 993-1001.

[135] Fujita M, Shannon JM, Irvin CG, et al. Overexpression of tumor necrosis factor-alpha produces an increase in lung volumes and pulmonary hypertension. Am J Physiol Lung Cell Mol Physiol 2001; 280: L39-49,

[136] Churg A, Wang RD, Tai H, Wang XS, Xie CS, Wright JL. Tumor necrosis factor-alpha drives $70 \%$ of cigarette smoke-induced emphysema in the mouse. Am J Respir Crit Care Med 2004; 170: 492-8.

[137] Gensch E, Gallup M, Sucher A, et al. Tobacco smoke control of mucin production in lung cells requires oxygen radicals AP-1 and JNK. J Biol Chem 2004; 279: 39085-93.

[138] Landschulz WH, Johnson PF, Adashi EY, Graves BJ, McKnight SL. Isolation of a recombinant copy of the gene encoding C/EBP. Genes Dev 1988; 2: 786-800.

[139] Graves BJ, Johnson PF, McKnight SL. Homologous recognition of a promoter domain common to the MSV LTR and the HSV tk gene. Cell 1986; 44: 565-76.

[140] Nerlov C. The C/EBP family of transcription factors: a paradigm for interaction between gene expression and proliferation control. Trends Cell Biol 2007; 17: 318-24.

[141] Rosen ED, Hsu CH, Wang X, et al. C/EBPalpha induces adipogenesis through PPARgamma: a unified pathway. Genes Dev. 2002; 16: 22-6.

[142] Ramji DP, Foka P. CCAAT/enhancer-binding proteins: structure, function and regulation. Biochem J 2002; 365: 561-75.

[143] Birkenmeier EH, Gwynn B, Howard S, et al. Tissue-specific expression, developmental regulation, and genetic mapping of the gene encoding CCAAT/enhancer binding protein. Genes Dev 1989; 3: 1146-56.

[144] Hendricks-Taylor LR, Darlington GJ. Inhibition of cell proliferation by $\mathrm{C} / \mathrm{EBP}$ alpha occurs in many cell types, does not require the presence of $\mathrm{p} 53$ or $\mathrm{Rb}$, and is not affected by large T-antigen. Nucleic Acids Res 1995; 23: 4726-33.

[145] Johnson PF. Molecular stop signs: regulation of cell-cycle arrest by C/EBP transcription factors. J Cell Sci 2005; 118: 2545-55.

[146] Umek RM, Friedman AD, McKnight SL. CCAAT-enhancer binding protein: a component of a differentiation switch. Science 1991; 251: 288-92.

[147] Lasa A, Carnicer MJ, Aventín A, et al. MEIS 1 expression is downregulated through promoter hypermethylation in AML1-ETO acute myeloid leukemias. Leukemia 2004; 18: 1231-7.
[148] Helbling D, Mueller BU, Timchenko NA, et al. The leukemic fusion gene AML1-MDS1-EVI1 suppresses CEBPA in acute myeloid leukemia by activation of Calreticulin. Proc Natl Acad Sci USA 2004; 101: 13312-7.

[149] Koschmieder S, Halmos B, Levantini E, Tenen DG. Dysregulation of the C/EBPalpha differentiation pathway in human cancer. J Clin Oncol 2009; 27: 619-28.

[150] Timchenko NA, Wilde M, Nakanishi M, Smith JR, Darlington GJ. CCAAT/enhancer-binding protein $\{$ alpha $\}$ (C/EBP $\{$ alpha $\})$ inhibits cell proliferation through the p21 (WAF-1/CIP-1/SDI-1) protein. Genes Dev 1996; 10: 804-15.

[151] Rüdiger JJ, Roth M, Bihl MP, et al. Interaction of C/EBP \{alpha\} and the glucocorticoid receptor in vivo and in non-transformed human cells. FASEB J 2002; 16: 177-84.

[152] Roth M, Johnson PR, Rudiger JJ, et al. Interaction between glucocorticoids and beta2 agonists on bronchial airway smooth muscle cells through synchronised cellular signalling. Lancet 2002; 360: 1293-9.

[153] Eickelberg O, Roth M, Lorx R, et al. Ligand-independent activation of the glucocorticoid receptor by beta2-adrenergic receptor agonists in primary human lung fibroblasts and vascular smooth muscle cells. J Biol Chem 1999; 274: 1005-10.

[154] Muller C, Alunni-Fabbroni M, Kowenz-Leutz, E, Mo X, Tommasino M, Leutz A. Separation of C/EBPalpha-mediated proliferation arrest and differentiation pathways. Proc Natl Acad Sci USA 1999; 96: 7276-81.

[155] Calkhoven CF, Müller C, Leutz A. Translational control of C/EBP alpha and C/EBPbeta isoform expression. Genes Dev 2000; 14 : 1920-32.

[156] Ossipow V, Descombes P, Schibler U. CCAAT/enhancer-binding protein mRNA is translated into multiple proteins with different transcription activation potentials. Proc Natl Acad Sci USA 1993; 90: 8219-23.

[157] Descombes P, Schibler U. A liver-enriched transcriptional activator protein, LAP, and a transcriptional inhibitory protein, LIP, are translated from the same mRNA. Cell 1991; 67: 69-79.

[158] Calkhoven CF, Snippe L, Ab G. Differential stimulation by CCAAT/enhancer-binding protein alpha isoforms of the estrogenactivated promoter of the very-low-density apolipoprotein II gene, Eur J Biochem 1997; 249: 113-20.

[159] Raught B, Gingras AC, James A, Medina D, Sonenberg N, Rosen JM. Expression of a translationally regulated, dominant-negative CCAAT/enhancer-binding protein beta isoform and up-regulation of the eukaryotic translation initiation factor 2alpha are correlated with neoplastic transformation of mammary epithelial cells. Cancer Res 1996; 56: 4382-6.

[160] Kozak M. An analysis of 5'-noncoding sequences from 699 vertebrate messenger RNAs. Nucleic Acids Res 1987; 15: 8125-48.

[161] Meurs E, Chong K, Galabru J, et al. Molecular cloning and characterization of the human double-stranded RNA-activated protein kinase induced by interferon. Cell 1990; 62: 379-90.

[162] Dever TE. Gene-specific regulation by general translation factors. Cell 2002; 108: 545-56.

[163] Lawrence JC Jr, Abraham RT. PHAS/4E-BPs as regulators of mRNA translation and cell proliferation. Trends Biochem Sci 1997; $22: 345-9$.

[164] Lin TA, Kong X, Haystead TA, et al. PHAS-I as a link between mitogen-activated protein kinase and translation initiation. Science 1994; 266: 653-6.

[165] Pause A, Belsham GJ, Gingras AC, et al. Insulin-dependent stimulation of protein synthesis by phosphorylation of a regulator of 5'-cap function. Nature 1994; 371: 762-7.

[166] Brunn GJ, Hudson CC, Sekulić A, et al. Phosphorylation of the translational repressor PHAS-I by the mammalian target of rapamycin. Science 1997; 277: 99-101.

[167] Peterson RT, Desai BN, Hardwick JS, Schreiber SL. Protein phosphatase $2 \mathrm{~A}$ interacts with the $70-\mathrm{kDa}$ S6 kinase and is activated by inhibition of FKBP12-rapamycinassociated protein. Proc Natl Acad Sci USA 1999; 96: 4438-42.

[168] Gingras AC, Raught B, Sonenberg N. eIF4 initiation factors: effectors of mRNA recruitment to ribosomes and regulators of translation. Annu Rev Biochem 1999; 68: 913-63. 
[169] Mathews MB, Sonenberg N, Hershey JWB. Translational Control of Gene Expression. Cold Spring Harbor: Laboratory Press 2000; pp 467-86.

[170] Wiesenthal V, Leutz A, Calkhoven CF. Analysis of translation initiation using a translation control reporter system. Nat Protoc 2006; 1: 1531-7.

[171] Wiesenthal V, Leutz A, Calkhoven CF. A translation control reporter system (TCRS) for the analysis of translationally controlled processes in the vertebrate cell. Nucleic Acids Res 2006; 34: e23.

[172] Pöyry TA, Kaminski A, Jackson RJ. What determines whether mammalian ribosomes resume scanning after translation of a short upstream open reading frame? Genes Dev 2004; 18: 62-75.

[173] Calkhoven CF, Muller C, Martin R, Krosl G, Pietsch H, Hoang T, Leutz A. Translational control of SCL-isoform expression in hematopoietic lineage choice. Genes Dev 2003; 17: 959-64.

[174] Harding HP, Novoa I, Zhang Y, Zeng H, Wek R, Schapira M, Ron D. Regulated translation initiation controls stress-induced gene expression in mammalian cells. Mol Cell 2000; 6: 1099-108.

[175] Cazzola M, Skoda RC, Translational pathophysiology: a novel molecular mechanism of human disease. Blood 2000; 95: 3280-8.

[176] Polymenis M, Schmidt EV. Coupling of cell division to cell growth by translational control of the G1 cyclin CLN3 in yeast. Genes Dev 1997; 11: 2522-31.

[177] Rogers GW Jr, Edelman GM, Mauro VP. Differential utilization of upstream AUGs in the beta-secretase mRNA suggests that a shunting mechanism regulates translation. Proc Natl Acad Sci USA 2004; 101: 2794-9.

[178] Timchenko LT, Iakova P, Welm AL, Cai ZJ, Timchenko NA. Calreticulin interacts with $\mathrm{C} / \mathrm{EBPalpha}$ and $\mathrm{C} / \mathrm{EBPbeta}$ mRNAs and represses translation of C/EBP proteins. Mol Cell Biol 2002; 22: 7242-57.

[179] Helbling D, Mueller BU, Timchenko NA, et al. CBFB-SMMHC is correlated with increased calreticulin expression and suppresses the granulocytic differentiation factor CEBPA in AML with inv(16). Blood 2005; 106: 1369-75.

[180] Kawagishi H, Wakoh T, Uno H, et al. Hzf regulates adipogenesis through translational control of C/EBPalpha. EMBO J 2008; 27: 1481-90.

[181] Mathews MB, Sonenberg N, Hershey JWB Translational Control of Gene Expressio. Cold Spring Harbor: Laboratory Press: USA 2000; pp 1-31

[182] Harding HP, Zeng H, Zhang Y, Jungries R, Chung P, Plesken H, Sabatini DD, Ron D. Diabetes mellitus and exocrine pancreatic dysfunction in perk $-/-$ mice reveals a role for translational control in secretory cell survival. Mol Cell 2001; 7: 1153-63.

[183] Scheuner D, Song B, McEwen E, et al. Translational control is required for the unfolded protein response and in vivo glucose homeostasis. Mol Cell 2001; 7: 1165-76.

[184] Delépine M, Nicolino M, Barrett T, Golamaully M, Lathrop GM, Julier C. EIF2AK3, encoding translation initiation factor 2- $\alpha$ kinase 3 , is mutated in patients with Wolcott-Rallison syndrome. Nat Genet 2000; 25: 406-9.

[185] Leegwater PA, Vermeulen G, Könst AA, et al. Subunits of the translation initiation factor eIF2B are mutant in leukoencephalopathy with vanishing white matter. Nat. Genet 2001; 29: 383-8.

[186] Lazaris-Karatzas A, Montine KS, Sonenberg N. Malignant transformation by a eukaryotic initiation factor subunit that binds to mRNA 5' cap. Nature 1990; 345: 544-7.

[187] Rosenwald IB, Chen JJ, Wang S, Savas L, London IM, Pullman J. Upregulation of protein synthesis initiation factor eIF-4E is an early event during colon carcinogenesis. Oncogene 1999; 18: 250717.

[188] Anthony B, Carter P, De Benedetti A. Overexpression of the protooncogene/ translation factor $4 \mathrm{E}$ in breast-carcinoma cell lines. Int $\mathrm{J}$ Cancer 1996; 65: 858-63.

[189] DeFatta RJ, Turbat-Herrera EA, Li BD, Anderson W, De Benedetti A. Elevated expression of eIF4E in confined early breast cancer lesions: possible role of hypoxia. Int J Cancer 1999; 80: 516-22.
[190] Wang S, Rosenwald IB, Hutzler MJ, et al. Expression of the eukaryotic translation initiation factors $4 \mathrm{E}$ and $2 \alpha$ in non-Hodgkin's lymphomas. Am J Pathol 1999; 155: 247-55.

[191] Crew JP, Fuggle S, Bicknell R, Cranston DW, de Benedetti A, Harris AL. Eukaryotic initiation factor-4E in superficial and muscle invasive bladder cancer and its correlation with vascular endothelial growth factor expression and tumour progression. $\mathrm{Br} \mathrm{J}$ Cancer 2000; 82: 161-6.

[192] Perrotti D, Cesi V, Trotta R, et al. BCR-ABL suppresses C/EBP $\alpha$ expression through inhibitory action of hnRNP E2. Nat Genet 2002; 30: 48-58.

[193] Rask K, Thörn M, Pontén F, et al. Increased expression of the transcription factors CCAAT-enhancer binding protein- $\beta(\mathrm{C} / \mathrm{EBP} \beta)$ and $\mathrm{C} / \mathrm{EBP} \zeta$ (CHOP) correlate with invasiveness of human colorectal cancer. Int J Cancer 2000; 86: 337-43.

[194] Cram EJ, Ramos RA, Wang EC, Cha HH, Nishio Y, Firestone GL. Role of the CCAAT/enhancer binding protein-alpha transcription factor in the glucocorticoid stimulation of $\mathrm{p} 21 \mathrm{wafl} / \mathrm{cip} 1$ gene promoter activity in growth-arrested rat hepatoma cells. J Biol Chem 1998; 273: 2008-14.

[195] Cha HH, Cram EJ, Wang EC, Huang AJ, Kasler HG, Firestone GL. Glucocorticoids stimulate p21 gene expression by targeting multiple transcriptional elements within a steroid responsive region of the p21wafl/cip1 promoter in rat hepatoma cells. J Biol Chem 1998; 273: 1998-2007.

[196] Borger P, Matsumoto H, Boustany S, et al. Disease-specific expression and regulation of CCAAT/enhancer-binding proteins in asthma and chronic obstructive pulmonary disease. J Allergy Clin Immunol 2007; 119: 98-105.

[197] Miglino N, Roth M, Tamm M, Borger P. House dust mite extract down-regulates $\mathrm{C} / \mathrm{EBPalpha}$ in asthmatic bronchial smooth muscle cells. Eur Respir J 2011; 38: 50-8.

[198] Plopper CG, Smiley-Jewell SM, Miller LA, et al. Asthma/allergic airways disease: does postnatal exposure to environmental toxicants promote airway pathobiology? Toxicol Pathol 2007; 35: 97-110.

[199] Ma X, Cheng Z, Kong H, et al. Changes in biophysical and biochemical properties of single bronchial smooth muscle cells from asthmatic subjects. Am J Physiol Lung Cell Mol Physiol 2002; 283: L1181-9.

[200] Stephens NL, Li W, Jiang H, Unruh H, Ma X. The biophysics of asthmatic airway smooth muscle. Respir Physiol Neurobiol 2003; 137: $125-40$.

[201] Shore SA. Airway smooth muscle in asthma: not just more of the same. N Engl J Med 2004; 351: 531-2.

[202] Sekiya T, Tsunemi Y, Miyamasu M, et al. Variations in the human Th2-specific chemokine TARC gene. Immunogenetics 2003; 54 742-5.

[203] Borger P, Black JL, Roth M. Asthma and the CCAAT-enhancer binding proteins: a holistic view on airway inflammation and remodelling. J Allergy Clin Immunol 2002; 110: 841-6.

[204] Lin SJ, Shu PY, Chang C, Ng AK, Hu CP. IL-4 suppresses the expression and the replication of hepatitis $B$ virus in the hepatocellular carcinoma line Hep38. J Immunol 2003; 171: 470816.

[205] Betz M, Fox BS. Prostaglandin E2 inhibits production of Th1 lymphokines but not of Th2 lymphokines. J Immunol 1991; 146: 108-13.

[206] Zhu Y, Saunders MA, Yeh H, Deng WG, Wu KK. Dynamic regulation of cyclooxygenase-2 promoter activity by isoforms of CCAAT/enhancer-binding proteins. J Biol Chem 2002; 277: 69238.

[207] Didon L, Qvarford I, Andersson O, Nord M, Riise GC. Decreased CCAAT/enhancer binding protein transcription factor activity in chronic bronchitis and COPD. Chest 2005; 127: 1341-6.

[208] Borger P, Koëter GH, Timmerman JAB, Vellenga E, Tomee JFC, Kauffman HF. Proteases from Aspergillus fumigatus induce interleukin (IL)-6 and IL-8 production in airway epithelial cell lines by transcriptional mechanisms. J Infect Dis 1999; 180: 1267-74. 
[209] Kuang PP, Goldstein RH. Regulation of elastin gene transcription by interleukin-1 beta-induced C/EBP beta isoforms. Am J Physiol Cell Physiol 2003; 285: C1349-55.
[210] Shim M, Smart RC. Lithium stabilizes the CCAAT/enhancerbinding protein alpha (C/EBPalpha) through a glycogen synthase kinase 3 (GSK3)-independent pathway involving direct inhibition of proteasomal activity. J Biol Chem 2003; 278(22): 19674-81.

(C) Miglino et al.; Licensee Bentham Open.

This is an open access article licensed under the terms of the Creative Commons Attribution Non-Commercial License (http://creativecommons.org/licenses/by-nc/3.0/) which permits unrestricted, non-commercial use, distribution and reproduction in any medium, provided the work is properly cited. 